\title{
Determining and Prioritizing Factors Affecting Customers Attraction of Medical Tourism from the Perspective of Arabic Countries (Case Study: Iran-Mashhad Razavi Hospital)
}

\author{
Farhad Saadatnia $^{1} \&$ Mohammad Reza Mehregan ${ }^{1}$ \\ ${ }^{1}$ School of Business Management, Tehran University, Tehran, Iran \\ Correspondence: Farhad Saadatnia, School of Business Management, Tehran University, Tehran, Iran, Tel: \\ 98-915-311-7556. E-mail: Farhadsaadatnia@yahoo.com
}

Received: May 24, 2013 Accepted: April 8, $2014 \quad$ Online Published: May 21, 2014

doi:10.5539/ijms.v6n3p155 URL: http://dx.doi.org/10.5539/ijms.v6n3p155

\begin{abstract}
Today, combination of medicine and tourism has turned into a new form of industry called health tourism. Health tourism industry has experienced a dramatic growth over the last decade. This industry is an opportunity for hospitals to extend their services to patients from other countries. The present study aims to identify factors contributing to the attraction of medical tourism along with ranking factors affecting customer satisfaction of Persian Gulf Countries .For this purpose, after studying the existing literature and matching the resulting data with the environmental conditions of the study six factors "the expertise and skill level of the hospital staff", "hospital facilities and equipments", "costs", "the way patients are treated by the staff and their relationship", "shared beliefs and values", "tourist and travel facilities" were determined and based on them questionnaires were designed and distributed to a number of patients of Persian Gulf Countries as well as the managers of the Razavi Hospital in Mashhad, where specialized medical tourism services are provided .Investigations indicated that from the viewpoint of both managers and patients, the most important factor affecting the attraction of the medical tourism of Razavi Hospital in Mashhad is the costs. These costs consist of medical expenses (such as hospital, medicine and tests costs), costs of travel and accommodation (such as hotel and guesthouse), transportation costs within the city and side expenditures (including visiting pilgrimage places and entertainment spots). Therefore, lowering the costs of medical treatments can be a strategy that the hospitals can benefit from in order to enter the medical tourism market.
\end{abstract}

Keywords: health tourism, medical tourism, medical tourism market, medical expenses

\section{Introduction}

Tourism industry is one of the most important ways of attracting revenues today. Devoting proper attention to this industry can provide employment opportunities as well as attracting revenues for the country. The attraction of these financial resources from the other side of the borders can play an important role in the development of the country. Due to the availability of the necessary potentials and resources for development, countries can greatly benefit from this industry. Medical tourism is considered one of the most important ways of attracting tourists.

Realizing the importance of this need of the $21^{\text {st }}$ century man, countries are determined to seize the existing opportunities in an area called "medical tourism".

World Tourism Organization (WTO) defines health tourism as "benefiting from services which result in improvement or increase in people's physical and psychological health, using mineral water, favorable weather or medical interventions which happens in a place away from the individual's residence and last more than 24 hours" (World Health Tourism).

\subsection{Significance of the Study}

A large number of the patients from the neighboring countries of Iran spend large amount of money to travel to European and American countries to receive medical services while, considering the cultural characteristics of rich Arab families and the existence of similar eating habits and other commonalities with Iranians, in 
comparison with European countries, there is enough motivation for attracting such tourists to Iran which is in a good position in terms of equipments and human resources.

Iran has great potentials with regards to health tourism, due to the development of modern clinics and hospitals such as Shahid Sadughi infertility treatment center in Yazd, dental and dialysis centers and various operations which are regularly carried out in hospitals in Mashhad and Tehran such as heart surgery, plastic surgery, eye surgery, orthopedics and bone marrow, kidney and liver transplant in Shahid Namzi Hospital in Shiraz (Health Tourism in Iran, 2009). There are also natural resources among which one can mention desert areas in Qom or water springs which traditionally used for taking hydrotherapy treatments and mineral baths . The low cost and high quality of the medical services along with the use of the latest technologies constitute the most important factors of the potential success of medical tourism in Iran (Poolnews, 2008). There are not exact statistics available regarding the number of health tourists visiting the country but according to the related authorities, annually 20000 health tourists travel to Iran form the Persian Gulf countries and Iraq (Ebtekar, 2009).

Through determining the present strengths and weaknesses of our hospitals, it is possible to identify the contributing factors to attract of foreign patients and to improve them considering the present potentials and threats which can in turn lead to success in the global competition in the field of medical tourism. Unfortunately, we still face lack of enough research concerning the affecting factors in the attraction of medical tourists, especially in areas which exhibit more potential for tourist attraction, such as the Persian Gulf. The present study attempts:

1) To identify main factors from the viewpoint of the Arab medical tourists

2) To test the positive influence of main factors on medical tourist attraction

3) To divide main factors to side factors

4) To rank main and side factors from viewpoints of managers and patients

\section{Literature Review}

In the last decade the medical tourism industry has become large. Deloitte (2008a) estimated that the world medical tourism market in 2008 was around US\$ 60 billion and that it is expected to grow to US\$ 100 billion by 2010. It is also estimated that around 6 million people a year worldwide will travel for medical care by 2010 (Herrick, 2008). Whereas at the beginning of the rise of the medical tourism industry there were only a handful of hospitals and only about 4 or 5 countries promoting themselves as medical tourism destinations, today there are hundreds of hospitals and clinics and over thirty different countries promoting it (Edelheit, 2009).

Factors contributing to the growth of medical tourism are closely intertwined. Authors agree that rising health care costs in industrialized countries coupled with the availability of high-quality medical services at significantly lower prices in developing countries has become the primary incentive for patients seeking treatments abroad (Deloitte, 2008a).

While economic benefits are central to medical tourism, there are other factors in play. According to Mattoo and Rathindran (2006), most medical travel is for procedures that are not adequately covered by home-country health insurance. For example, health insurance plans usually do not cover various forms of dental or cosmetic surgeries (Connell, 2006). In countries where there is no widespread national healthcare, the lack of adequate health insurance, or no health insurance at all, are some of the reasons motivating people to seek treatments abroad (Caballero-Danell \& Mugomba, 2007). This is particularly true for medical tourists from the United States where according to the U.S. Census Bureau (2009) there were 46.3 million uninsured in 2008.

But even in countries where there is a national healthcare program, as in Canada and the United Kingdom for instance, patients are also willing to travel abroad for health care in order to have timely treatment and avoid long waiting lists at home. In all these cases, patients thoroughly compare prices and services offered by alternative institutions. With the emergence of state-of-the-art facilities and high skilled doctors in many important medical tourism destinations, patients do not even have to sacrifice quality for prices anymore. Mattoo and Rathindran (2006) add that there is significant evidence that the upper-end of the quality distribution of both professionals and hospitals in several advanced developing countries lies well above the minimum acceptable standard in industrial countries. Because of this, many medical tourism destinations are proud to offer "first-class services at third-world prices."

An additional factor that has fuelled the growth of medical tourism is the aging of the population globally. The fact that people are living longer and enjoying more retirement time means on the one hand, that there is a growing number of people with higher discretionary incomes and more time to travel. On the other hand, the 
aging of the population also translates into a larger number of people experiencing chronic health conditions, such as diabetes and hypertension and having a need for various kinds of specialized health services. There are 78 million baby boomers in the United States alone and this segment of the population is increasingly interested in traveling abroad to meet their health needs (Ross, 2002). For instance, the population aged 60 years or older accounted for $10 \%$ of total arrivals to the Caribbean in 1998 (Gonzales, Brenzel, \& Sancho, 2001). Although not all of these travelers were medical tourists, the authors suggest that health tourism designed around the needs of seniors is a potential successful business for the region.

Medical tourists also choose to obtain health care in a foreign country because a treatment abroad may guarantee privacy and confidentiality, which many patients prefer especially when undergoing treatments such as plastic surgery. Patients also travel abroad in search of procedures that are not available or are illegal in their home countries such as stem cell therapy, drug rehabilitation or sex change procedures (Horowitz, Rosensweig, \& Jones, 2007). Finally, when choosing to travel to a specific country in search of a medical treatment, there are several factors that come into play. For example, geographical and cultural proximity, medical specializations, reputation and portability of health insurance are some of the reasons for a person's choice of one country over another (Bookman \& Bookman, 2007).

Bookman and Bookman (2007) add that other factors that have contributed to an increase in the supply of medical tourism include the liberalization of trade in services, the growing cooperation between private and public sectors and, most importantly, the successful merging "splicing" of the tourism and health sectors.

The development and expansion of medical tourism has not only been demand-led but has also resulted from the countries' ability of supplying high quality medical services at significantly lower prices. Strong economic growth in developing countries has provided the resources and opportunities to improve capacity and infrastructure constraints that had hindered the development of this industry in the past (Deloitte, 2008a).

\section{Methodology}

The present pragmatic study based on the data collection aims to rank the factors contributing in the numbers of medical tourists from Arabic countries. The ranking of the factors affecting the satisfaction of patients from the point of view of hospital managers is carried out through the analytical hierarchy process.

The study population consists of two groups. The first group is all the patients of the Persian Gulf counties who visit Razavi Hospital and the second group includes the director of Finance and Administration, Finance and Administrative Assistant, Research Director and Assistant, Chief of Emergency Services and Head Nurse of the hospital.

In the first stage of the study, the opinions of the patients (as the customers) with regards to the contributing factors to the increase of medical tourist attraction are analyzed. 32 visiting patients from Arab countries are randomly selected and their opinions were compared with those of 6 managers and experts in terms of the ranking of the contributing factors.

This study designs two questionnaires. They consist of six sections, each of which studies one of the following factors: "expertise and skills of the hospital staff", "hospital facilities and equipment","costs", "the behavior of staff towards the patients and their relationship", "shared ethical and religious beliefs", "tourist and travel facilities".

The questionnaire designed for the managers questions the main factors identified in the literature review using a Matrix of Paired Comparisons and determines the principle criteria through six Paired Matrixes. Also, in order to determine the importance of each criterion in comparison to others in the Paired Comparisons Matrix, the range of one to nine hours is employed.

The patients' questionnaire consists of six different sections based on each main factor. Each section of this questionnaire includes the criteria of each factor and a 7-point Likert scale is used to provide a scale starting from the lowest weight (1) to the highest (7).

\section{Results and Discussions}

\subsection{The Demographic Characteristics of the Sample}

Table 1 demonstrates the distribution of the sample according to the Arab counties of the Persian Gulf. 
Table 1. Distribution of the sample according to the Arab countries

\begin{tabular}{lll}
\hline Row & Countries & Frequency \\
\hline 1 & Arabia & 2 \\
2 & Iraq & 13 \\
3 & Yemen & 6 \\
4 & Lebanon & 4 \\
5 & Kuwait & 3 \\
6 & United Arab Emirates & 3 \\
7 & Qatar & 1 \\
\hline
\end{tabular}

The sample consists of 10 female and 20 male patients from which 20 patients have associate degree and 12 patients have higher education. The director's sample includes six senior managers with over 15 years working experience and $\mathrm{PhD}$ degrees.

\subsection{The Inferential Analysis of Data}

In this section the impact of the identified factors on the increase of medical tourism attraction is tested. Every case is tested with $95 \%$ confidence level.

$\mathrm{H}_{0}: \mu \leqslant 4$

$\mathrm{H}_{1}: \mu>4$

Table 2. T-Test of the six determined factors at $95 \%$ significance

\begin{tabular}{lllllll}
\hline Assumptions & $\begin{array}{l}\text { Upper } \\
\text { limit }\end{array}$ & $\begin{array}{l}\text { Lower } \\
\text { limit }\end{array}$ & $\begin{array}{l}\text { Mean } \\
\text { difference }\end{array}$ & Sig & t-Test Stat & $\begin{array}{l}\text { Degree of } \\
\text { freedom }\end{array}$ \\
\hline $\begin{array}{l}\text { expertise and skills of the hospital staff is a } \\
\text { contributing factor to the attraction of medical } \\
\text { tourism }\end{array}$ & 0.816 & 0.541 & 0.679 & 0.000 & 9.788 & 31 \\
$\begin{array}{l}\text { Hospital facilities and equipment are contributing } \\
\text { factors to the attraction of medical tourism }\end{array}$ & 0.923 & 0.699 & 0.811 & 0.000 & 14.366 & 31 \\
$\begin{array}{l}\text { Treatment cost is a contributing factor to the } \\
\text { attraction of medical tourism }\end{array}$ & 0.997 & 0.844 & 0.920 & 0.000 & 23.947 & 31 \\
$\begin{array}{l}\text { Relationships and the way patients are treated by } \\
\text { the staff are contributing factors to the attraction of } \\
\text { medical tourism }\end{array}$ & 1.096 & 0.891 & 0.993 & 0.000 & 19.238 & 31 \\
$\begin{array}{l}\text { Ethical and religious beliefs of the patients are } \\
\text { contributing factors to the attraction of medical } \\
\text { tourism }\end{array}$ & 0.864 & 0.728 & 0.796 & 0.000 & 23.232 & 31 \\
$\begin{array}{l}\text { Tourist and travel facilities are contributing factors } \\
\text { to the attraction of medical tourism }\end{array}$ & 0.877 & 0.481 & 0.679 & 0.000 & 6.799 & 31 \\
\hline
\end{tabular}

By rejecting the $\mathrm{H}_{0}$ theory with the confidence level of $95 \%$, the six selected factors can be accepted as contributing factors affecting the increase of medical tourism attraction in the country. At this stage the study will continue by prioritizing the mentioned factors based on results. First, factors are prioritized from the point of view of the patients of the Persian Gulf counties using Friedman test and the next stage will prioritize the same factors from the viewpoint of the authorities of Mashhad Razavi Hospital using AHP technique. 
4.3 Prioritizing the Contributing Factors in the Attraction of Medical Tourism from the Viewpoint of Customers: Using Friedman Test, the Priority of Each Mixed Marketing Element Is Determined

Table 3. Friedman test of the six main and side factors

\begin{tabular}{|c|c|c|c|c|c|}
\hline Rankings & Main factors & Value & Side factors & Rankings & value \\
\hline \multirow[t]{5}{*}{1} & \multirow[t]{5}{*}{ Costs } & \multirow[t]{5}{*}{5.23} & Medical expenses (hospital, medicine, tests and etc.) & 1 & 5.48 \\
\hline & & & Accommodation costs (hotels, costs and etc.) & 2 & 5.13 \\
\hline & & & Travel tour fees & 3 & 4.34 \\
\hline & & & Costs of transportation within the city & 4 & 4.19 \\
\hline & & & $\begin{array}{l}\text { Side expenditures of the travel (visiting pilgrimage places, } \\
\text { entertainment and etc.) }\end{array}$ & 5 & 4.10 \\
\hline \multirow[t]{8}{*}{2} & \multirow{8}{*}{$\begin{array}{l}\text { Expertise and } \\
\text { skills of the } \\
\text { hospital staff }\end{array}$} & \multirow[t]{8}{*}{4.03} & Availability of various medical expertise & 1 & 5.92 \\
\hline & & & Expertise and skills of physicians & 2 & 5.12 \\
\hline & & & Timely medical attention & 3 & 4.69 \\
\hline & & & Expertise and skills of technicians & 4 & 3.61 \\
\hline & & & International fame and achievements of the doctors & 5 & 3.57 \\
\hline & & & Nursing expertise & 6 & 2.85 \\
\hline & & & Timely nursing care & 7 & 2.24 \\
\hline & & & Coordination between medical and nursing staff & 8 & 2.02 \\
\hline \multirow[t]{6}{*}{3} & \multirow{6}{*}{$\begin{array}{l}\text { Hospital } \\
\text { facilities and } \\
\text { equipment }\end{array}$} & \multirow[t]{6}{*}{3.52} & Laboratory equipments and facilities & 1 & 5.59 \\
\hline & & & sick room equipment and facilities & 2 & 4.99 \\
\hline & & & operation room equipment and facilities & 3 & 4.22 \\
\hline & & & Ambulance equipment and facilities & 4 & 3.79 \\
\hline & & & Intensive care equipment and facilities (ICU, CCU and etc.) & 5 & 3.57 \\
\hline & & & Hospital hygiene & 6 & 3.17 \\
\hline \multirow[t]{3}{*}{4} & \multirow{3}{*}{$\begin{array}{l}\text { Values and } \\
\text { beliefs }\end{array}$} & \multirow[t]{3}{*}{3.50} & Islamic values in the hospital environment & 1 & 4.37 \\
\hline & & & Compliance with religious laws in providing medical services & 2 & 3.58 \\
\hline & & & Religious environment of the city & 3 & 3.16 \\
\hline \multirow[t]{6}{*}{5} & \multirow{6}{*}{$\begin{array}{l}\text { The way } \\
\text { patients are } \\
\text { treated by the } \\
\text { staff }\end{array}$} & \multirow[t]{6}{*}{3.28} & Doctors' attitudes and attention & 1 & 5.30 \\
\hline & & & Respect for patient privacy & 2 & 5.23 \\
\hline & & & $\begin{array}{l}\text { The attitude and behavior of the information, reception and } \\
\text { security staff }\end{array}$ & 3 & 4.03 \\
\hline & & & Nurses attitudes and attention & 4 & 3.52 \\
\hline & & & Doctors' explanations regarding the medical proceedings & 5 & 3.50 \\
\hline & & & Filing speed & 6 & 3.28 \\
\hline \multirow[t]{5}{*}{6} & \multirow{5}{*}{$\begin{array}{l}\text { Travel and } \\
\text { tourist facilities }\end{array}$} & \multirow[t]{5}{*}{3.13} & Tour services & 1 & 4.69 \\
\hline & & & Ease of getting the visa & 2 & 4.62 \\
\hline & & & City transportation systems & 3 & 3.17 \\
\hline & & & Hotel facilities and services & 4 & 2.61 \\
\hline & & & Tourist attractions and entertainment centers of the city & 5 & 2.34 \\
\hline
\end{tabular}

Table above indicates that from the viewpoint of patients, the most important factor is the fees and under this main factor, the side factor of "medical expenses" (hospital, medicine, tests and etc.) is in the first place. Also the sixth place is occupied by "travel and tourist facilities" under which he side factor "tour services" finds the first place.

\subsection{Prioritizing the Contributing Factors to the Attraction of Medical Tourism from the Viewpoint of the Managers}

The relative weights of the contributing factors to the attraction of medical tourism from the point of view of the managers and authorities of Razavi Hospital of Mashhad were calculated using AHP and Exert Choice software.

After designing the model in Expert Choice and adding the paired scales, the weight of the contributing factors was calculated and table 9 exhibits the results. 
Table 4. The prioritizing of the contributing factors to the increase of the attraction of medical tourism from the viewpoint of the managers of Mashhad Razavi Hospital

\begin{tabular}{llll}
\hline Row & Main factor & weights & priority \\
\hline 1 & The way patients are treated by the staff & 0.144 & 4 \\
2 & Costs & 0.363 & 1 \\
3 & Hospital facilities and equipment & 0.229 & 2 \\
4 & Expertise and skills of the hospital staff & 0.173 & 3 \\
5 & Values and beliefs & 0.033 & 6 \\
6 & Travel and tourist facilities & 0.058 & 5 \\
\hline
\end{tabular}

Considering the results, the factors of costs, hospital facilities and equipment, expertise and skills of the hospital staff, the way patients are treated by the staff, tourist and travel facilities and values and beliefs respectively fill the places first to sixth.

The inconsistency rate is 0.05 in this decision matrix which is less than 0.1 and therefore acceptable.

Table 5. Comparison of the ranking of the contributing factors to the increase of medical tourist attraction from the viewpoint of the patients and hospital managers

\begin{tabular}{lll}
\hline Factors & $\begin{array}{l}\text { Ranking from the viewpoint of } \\
\text { patients }\end{array}$ & $\begin{array}{l}\text { Ranking from the viewpoint of } \\
\text { managers }\end{array}$ \\
\hline Expertise and skills of the hospital staff & 2 & 3 \\
Hospital facilities and equipment & 3 & 2 \\
Costs & 1 & 1 \\
The way patients are treated by the staff & 5 & 4 \\
Values and beliefs & 4 & 6 \\
Travel and tourist facilities & 6 & 5 \\
\hline
\end{tabular}

As indicated in the table, both groups consider the "costs" as the most important factor in the increase of medical tourist attraction in the Persian Gulf countries. The factor "expertise and skills of the hospital staff " and "hospital facilities and equipment" respectively take the second and third place from the point of view of patients while the managers consider the opposite and believe that "hospital facilities and equipment" have more priority than "expertise and skills of the hospital staff". Patients think that " ethical and religious beliefs" and "relationships and the behavior of the staff towards patients" should be in the fourth and fifth places but the managers think that "the behavior of the staff towards patients" and" travel and tourist facilities" come next. The most interesting point in this analysis is that from the viewpoint of patients," tours and travel facilities" have the lowest importance but the managers "believe values and beliefs" should have the lowest priority.

4.5 The Final Model and Weighted Means Based on the Patients' Answers

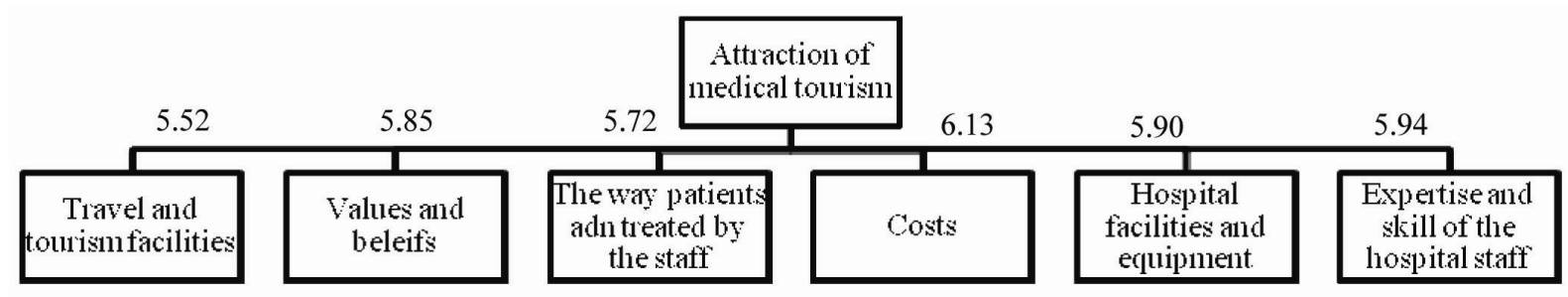

Figure 1. Final model

\section{Conclusions}

In this pragmatic study we have investigated factors which play crucial roles in increasing the number of medical tourists from Arabic countries based on the data collected from Razavi Hospital which is one of the main centers for medical tourism in the country. It is found out that with $95 \%$ statistical confidence level the six factors of "tourist and travel facilities", "expertise and skills of the hospital staff", "behavior of staff towards the patients 
and their relationship", "ethical and religious beliefs", "hospital facilities and equipment" and "costs" affect the increase of medical tourist attraction. From the view point of the patients and managers of Razavi Hospital of Mashhad, the most important contributing factor to the increase of medical tourist attraction is the fees. These fees consist of medical expenses (hospital, medicine, tests and etc.), travel tour fees, accommodation costs (hotels, costs and etc.), transportation costs within the city and side expenditures of the travel (visiting pilgrimage places, entertainment and etc.). Therefore it seems that the most important competitive advantage of hospitals and clinics of the country is the low cost of their services. Consequently, if they are willing to participate in the medical tourism market, they need to take actions to lower medical expenses.

Comparing other rankings of the mentioned table reveals that there is not a dramatic difference between the priorities of the two groups. For example, the last three factors (behavior of hospital staff towards patients, ethical and religious beliefs and tourist and travel facilities) and the second and third factors (expertise and skills of the hospital staff and hospital facilities and equipment) of both groups are the same. Table 5 also exhibits similarities between the opinions of the two groups which indicates correct identification and proper understanding of the patients' needs on the part of the managers of Mashhad Razavi Hospital.

\section{Acknowledgements}

Here I would like to extend my sincere gratitude to the managers, doctors and nurses of Mashhad Razavi Hospital who offered their warm-hearted cooperation over the various stages of this study.

\section{References}

Bookman, M. Z., \& Bookman, K. R. (2007). Medical Tourism in Developing Countries. New York: Palgrave Macmillan. http://dx.doi.org/10.1057/9780230605657

Caballero-Danell, S., \& Mugomba, C. (2007). Medical Tourism and its entrepreneurial opportunities-A conceptual framework for entry into the industry. Göteborg University, School of Business, Economics and Law, Master Thesis No. 2006:91.

Connell, J. (2006). Medical tourism: sea, sun, sand and surgery. Tourism Management, 27(6), 1093-1100. http://dx.doi.org/10.1016/j.tourman.2005.11.005

Deloitte. (2008a). Medical Tourism-Consumers in Search of Value. Deloitte Center for Health Solutions, Washington, D.C.

Ebtekar Issue, ICTO (Inheritance Cultural and Tourism Organization) Actions. (2008). Retrieved from http://www.ebtekarnews com.ebtekar.news.aspx?nid=4962

Edelheit, J. (2009). The effects of world economic recession on medical tourism. Medical Tourism Magazine, 1.

Gonzales, A., Brenzel, L., \& Sancho, J. (2001). Health Tourism and Related Services: Caribbean Development and International Trade. Document submitted to the Regional Negotiating Machinery (RNM), 31 August.

Health Tourism In Iran. (2009). Retrieved from http://tosea.iran.ir.?id=1695

Herrick, D. M. (2007). Medical Tourism: Global Competition in Health Care. National Center for Policy Analysis (NCPA) Policy Report No. 304, Dallas, Texas, November.

Horowitz, M. D., \& Rosensweig, J. A. (2007). Medical tourism-health care in the global economy. Physician Executive, 1 .

Horowitz, M. D., Rosensweig, J. A., \& Jones, C. A. (2007). Medical tourism: globalization of the healthcare marketplace. Medscape General Medicine, 9(4).

Mattoo, A., \& Rathindran, R. (2006). How health insurance inhibits trade in health care. Health Affairs, 25(2). http://dx.doi.org/10.1377/hlthaff.25.2.358

Poolnews Issue. (2008). The role of hospitals in advancement of medical tourism. Retrieved from http://www.poolnews.ir.fa.pages.?cid=844

Ross, K. (2001). Health tourism: an overview. Hospitality Net, December.

Teh, I., \& Chu, C. (2005). Supplementing growth with medical tourism. APBN, 9(8).

U.S. Census Bureau. (2009). Income, Poverty and Health Insurance Coverage in the United States: 2008. Current Population Reports, Washington D.C., September.

WTO (World Health Tourism). (1995). Collection of Tourism Expenditure Statistics. Retrieved from http://pub.worldtourism.org.WebRoot.Store.Shops.Info shop.Products.1034.1034-1.pdf 


\section{Copyrights}

Copyright for this article is retained by the author(s), with first publication rights granted to the journal.

This is an open-access article distributed under the terms and conditions of the Creative Commons Attribution license (http://creativecommons.org/licenses/by/3.0/). 